\title{
The Comparison of Self-Perception of the Use of Learning Strategies in Spanish and Lithuanian Secondary Students When Learning Science
}

\author{
Enric Ortega-Torres ${ }^{1}$, Sigitas Drąsutis ${ }^{2}$, Renata Burbaite $\dot{3}^{3}$
}

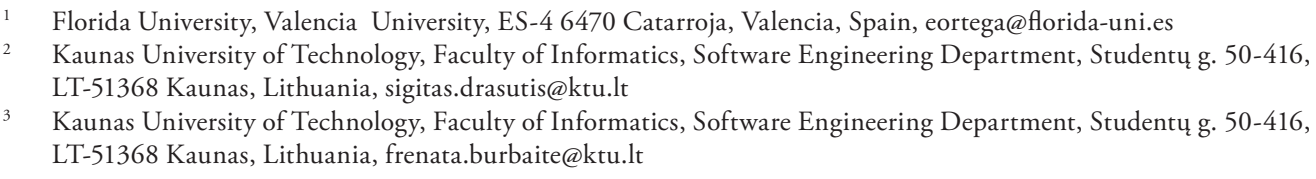

Annotation. Improving students' learning strategies is important for them in order to learn successfully. This article compares the self-perception of the use of learning strategies in Spanish and Lithuanian secondary schools students when learning science and analyse the students understanding of these strategies to determine the sociocultural environment influence on this perception. Results emphasize the need to include support actions to improve the management of strategies in secondary school.

Keywords: learning strategies, motivation, science education, secondary education, Motivated Strategies for Learning Questionnaire.

\section{Introduction}

Every student is different and may find different obstacles to learning. One of the main challenges for teachers all around the world is to adapt their learning plans to every difference, trying to give the best options for each student. The educational literature has exposed fixed factors on students that could help teachers to adapt their lessons to overcome these difficulties and improve the student's achievements. To find these factors become even more important on the school level with students living an 
important moment of change, transcendental for their future. Being able to recognize their difficulties in implementing some learning strategies could help teachers better to design their science learning plans.

\section{Importance of learning strategies on secondary education level students}

In addition to the cognitive, affective, and instructional prerequisites, metacognition has proved to be another influencing factor in academic achievement. Consistent evidence has been obtained on the academic benefits of proper development of metacognitive skills (Wang et al., 1993). Developing metacognition implies making students aware of their own strengths and weaknesses, and the possibility of transferring responsibility from teachers to students themselves to make decisions on learning processes. This is also the claim of the Constructivist approach to learning and teaching (Dewey, 2007). Students have to engage in planning, monitoring, and evaluating the learning goals, processes, and outcomes (Brown \& Palincsar, 1982) in order to be active learners and meaning-constructors. Thus, developing metacognitive skills should imply greater academic achievement, especially in science. The consciousness of the internal construction of meaning allows the early detection of discrepancies and incoherencies, and fosters the student's active use of resources at hand to overcome perceived learning obstacles.

Some questionnaires, further mentioned as good practice examples, developed to evaluate students' use of learning strategies have achieved great popularity among experts. This is the case of the Motivated Strategies for Learning Questionnaire (MSLQ onwards) developed by Pintrich et al. (1991) which is one of the most used to evaluate (the self-perception of the use of) strategies in educational contexts.

The MSLQ is based on a cognitive vision of learning strategies. Its validity has been analyzed in multiple and diverse contexts: Ilker (2014) with secondary school students in Turkey, also Curione (2017) with students of psychology in Uruguay, or Dorantes and collaborators (2013) with university students in Mexico, and Lee et al. (2010) in Hong Kong also with secondary school students.

MSLQ has been frequently used in the population of secondary education students to assess the association between self-perceived use of strategies and academic achievement. In general, significant effects were obtained in the prediction of the performance from the scores in all the scales (Veloo et al., 2015) or from particular scales, such as Self-Efficacy (Arslan, 2013; Bircan \& Sungur, 2016), or Task Value (Bircan \& Sungur, 2016).

\section{Research Focus}

Over the last ten years, the study of learning strategies has been an important field of research due to its involvement in the management of the students on their learning process and the relationship between some of these strategies with student's achievement (Ortega-Torres et al., 2018). Learning strategy can be understood as a sequence of specific activities that will enable the learner to gain new knowledge (Lewalter, 2003). Thus, 
learning strategies are cognitive actions that students perform in order to master academic tasks or attain particular learning goals (Bembenutty, 2009; Lynch, 2008). Previous research highlighted the importance of cognitive and motivational factors influencing students' learning strategies (Greene \& Miller, 1996). Mega and collaborators (2014) found a significant effect on academic achievement with the integration of motivational, cognitive and metacognitive factors managed by students on their learning process.

The results on the field of science learning have shown that some motivational components have an important influence on science academic achievement (Koballa \& Glynn, 2013; Sungur \& Güngören, 2009). In addition, Akyol et al. (2010) found a significant contribution of using cognitive and metacognitive strategies to secondary education students' achievement in science subjects. Bryan et al. (2011) also proved a significant relationship between secondary education students' motivational components, and science achievement.

\section{Research Aim and Research Questions}

The possibility of finding similarities in the management of learning strategies by secondary education students when they learn science in different sociocultural environments is relevant because these regular patterns can define general plans for the science learning process. To recognize these similitudes is a key factor for science teachers and open new options to plan science-learning plans valid worldwide.

Looking for these similitudes, to make a comparison between different sociocultural environments using the same research process and instruments was the objective of this research. Therefore, the research questions defined were the following:

Q1: What are the most used learning strategies in science subjects for secondary school students in Spain and Lithuania?

Q2. Are the learning strategies used by Spanish students the same as those of Lithuanian students in secondary school science education?

Q3. Do students from Spain and Lithuania have similar opinions about these concepts?

\section{Research Methodology}

A mixed methodology combining a quantitative and qualitative approach was used in this research. In the quantitative approach, the MSLQ questionnaire was adapted to a digital format to facilitate the process of collecting responses from different educational centers. The research started in Spain from January to May 2018 and replicated the same process in Lithuania in June 2018. The questionnaire was administered in a normal science class. Completion lasted less than $90 \mathrm{~min}$., and typically took 65-80 min. One of the researchers was present in the sessions to clarify participants' doubts. Excel and SPSS 24.0 were used to collect and to analyze data using descriptive and inferential statistics. 
The qualitative approach was based on semi-structured interviews with students carried out in Spain in May and June 2018 and in Lithuania in June 2018. The interviews were planned in an open way in order to be able to delve into some of the key aspects to be analyzed, in the sense of allowing the interviewer to stop on a specific aspect according to the answers.

Ethical procedure principles were followed in the research obtaining informed consent from schools and protecting anonymity and confidentiality of students.

\section{Sample}

Spain: A total of 365 secondary education students enrolled in courses from 7th to 11th grade participated in the present research. They belonged to 8 secondary schools located in the surroundings of Valencia - one of the biggest cities in Spain, to seek for the representation of students' diversity in the sample. Some students did not give complete data and then were excluded of particular statistical analyses.

Lithuania: a group of 65 secondary school students from Panevėžys, a city which is close to one of the largest cities in Lithuania, participated in the research. All students completed the questionnaire and were included on the statistical analyses.

The difference between the samples was due to the fact that the first part of the study was used to develop a dissertation thesis based on Spanish students (OrtegaTorres, 2019) and the second part in Lithuania was carried out to amplify this previous research with the analysis of the effects of the sociocultural environment described in this paper.

\section{Instrument}

The measures on self-perceived use of learning strategies in secondary school science subjects (Physics, Chemistry, Biology, Technology and Mathematics) for this study were obtained from the instrument called Motivated Strategies for Learning Questionnaire (MSLQ) defined by Pintrich et al. (1991).

The questionnaire contained three different sections.

- The motivation section consists of 31 items that assess the objectives of the students, the causes of these objectives and their beliefs about the value of learning in a certain course.

- The section on cognitive and metacognitive strategies that includes 31 items that evaluate the processing of information and the control of these processes.

- The resource management section to facilitate learning, consisting of 19 items designed to assess the use that students make of classmates, teachers, spaces, and times to facilitate their own learning.

In each of these three sections, there are several identifiable strategies or "scales", listed in Table 1. 
Table 1

Strategies and Items in the MSLQ Questionnaire

\begin{tabular}{lll}
\hline & & ITEMS \\
\hline & Motivational Section & \\
GO & Goal Orientation & $1-16-22-24$ \\
EO & Extrinsic Goal Orientation & $7-11-13-30$ \\
TV & Task Value & $4-10-17-23-26-27$ \\
LB & Control of Learning Beliefs & $2-9-18-25$ \\
SE & Self-Efficacy & $5-6-12-15-20-21-29-31$ \\
TA & Test Anxiety (Affective component) & $3-8-14-19-28$ \\
& Cognitive and Metacognitive Section & \\
R & Rehearsal & $39-46-59-72$ \\
E & Elaboration & $53-62-64-67-69-81$ \\
O & Organization & $32-42-49-63$ \\
CT & Critical Thinking & $38-47-51-66-71$ \\
MR & Metacognitive Self-Regulation & $33^{\star}-36-41-44-54-55-56-57^{\star}-61-76-78-79$ \\
& Management Section & \\
TE & Time And Study Environment & $35-43-52^{\star}-65-70-73-77^{\star}-80^{\star}$ \\
ER & Effort Regulation & $37^{\star}-48-60^{\star}-74$ \\
PE & Peer Learning & $34-45-50$ \\
SO & Support Of Others (Help Seeking) & $40^{\star}-58-68-75$ \\
& & \\
\hline
\end{tabular}

Each of these strategy is valued through a set of items with the connection between them. For example, in the section on cognitive and metacognitive strategies there is the scale called "E: Elaboration". This scale evaluates the use of strategies associated with the elaboration of the information provided to create a coherent mental representation of knowledge. This scale is made up of items \# 53-62-64-67-69-81, which have a close connection.

The following items show this connection:

\#53. When I study for this class, I pull together information from different sources, such as lectures, readings, and discussions.

\#62. I try to relate ideas in this subject to those in other courses whenever possible.

\#64. When reading for this class, I try to relate the material to what I already know.

The student has to self-assess the assertion in each item using a 7 points Likert scale, where 1 means "Not at all true of me" and 7 means "Very true of me". The score of each scale is obtained by averaging the items involved. 
MSLQ questionnaire was validated for secondary school students. Karadeniz et al. (2008) conducted a validation study in a Turkish context to adapt the MSLQ to male and female primary and secondary school students from 6th to 11th grades. Students in the sample were tested focusing on different academic subjects: mathematics, sciences, social sciences, and language. In order to compare results from this Turkish study to the present Spanish research data, we computed again a t-test and a Pearson's correlation for the two sets (Turkish/ Spanish) of fifteen mean values. The mean values were not significantly different and varied in parallel across the different components $(\mathrm{t}(14)=1.19 ; \mathrm{p}>.10)$; both sets of mean values were highly correlated $\mathrm{r}(15)=.79)$.

\section{Procedure}

In Spain all questionnaires were administered following the next stages: first of all, a brief explanation text was elaborated to explain to the participants the aims and possible benefits of the research, and to focus their attention on science learning along with secondary school. Second, after obtaining permission the science teacher was invited to participate in the research and then, he/she was instructed in the procedure to correctly administrate the questionnaire. The steps followed were:

Step 1: (10 minutes aprox.). The students went to the computer classroom. They stand in front of their computer in an order established by the teacher, turned on the device and download the questionnaire.

Step 2: (10 minutes aprox.). Instructions were provided with special insistence on centering attention to science learning only.

Step 3: (50 minutes aprox). Students filled the MSLQ questionnaire.

The total procedure took less than $1 \mathrm{~h} 15 \mathrm{~min}$ in any case.

Step 4: The filled-up questionnaires were evaluated by one of the researchers (EO), according to the particular procedure stablished for MSLQ instrument.

A month later, the researcher returned to schools and interviewed a group of selected students, the same number of boys and girls with representation at all educational levels. These interviews were transcribed and analysed following standard protocols: 1) Assignation of preliminary codes based on the strategies included on the MSLQ questionnaire. 2) Search for patterns across the different interviews. 3) Define similitudes and differences between samples. 4) Describe conclusions.

In Lithuania: the Lithuanian science and technology teacher (R.B) planned a similar protocol to pass the questionnaires to her students. It was agreed that the language of application was English. The teacher explained the process to students and through a virtual meeting with the group of students and the researcher (E.O) the general objectives of the research were explained and thank their collaboration (June 2018).

After completing the questionnaires, the researcher did a visit to the school (June 2018) to interview a group of students in order to know their interpretation of the questions and to amplify the results with a qualitative approach. 


\section{Research Results}

\section{Data analysis from MSLQ results}

As the 3 large blocks (Motivation, Cognitive \& Metacognitive, and Management) behave like an interval scale, we could obtain the average scores of the 3 blocks by adding the scores of the items they contain. The distribution of learning strategies averages obtained from the Spanish and Lithuanian students is shown in table 2:

Table 2

Mean Values of the 3 MSLQ Blocks for Spanish (SP) and Lithuanian (LTH) Students

\begin{tabular}{clcc}
\hline Sections and components & & Mean & SD \\
\hline Motivation (GO, EO, TV, LB, SE, TA) & & & \\
Motivation Block & SP & 5.06 & .84 \\
Cognitive \& Metacognitive (R, E, O, CT, MR) & LTH & 4.82 & 1.26 \\
Motivation Block & SP & 4.83 & .88 \\
Management (TE, ER, PE, SO) & LTH & 4.32 & 0.86 \\
Motivation Block & & & \\
& SP & 4.56 & .70 \\
& LTH & 4.63 & .99 \\
\hline
\end{tabular}

With these results the highlights of Spanish results: There is greater self-perceived use of Motivation (Mot) strategies (Global Average Value = 5.06). This section is followed by the Cognition-Metacognition (CogMet) one (Global Average Value $=4.64$ ), and the Resource Management $(\mathrm{Adm})($ Global Average Value $=4.56)$. Spanish Sections' relation can be summarized by:

$$
\operatorname{Adm}(4.56)<\operatorname{Cog} M e t(4.64)<\operatorname{Mot}(5.06) \text {. }
$$

Considering the Motivation section, the strategy with the lowest value is TA (Test Anxiety), which shows a much lower value with an average of 4.67 . The highest one is GO (Goal Orientation) with 5.17. In the section on Cognitive and Metacognitive strategies, there is an important difference between the strategies of greatest use and those of least use, finding the lowest value of this section for $\mathrm{R}$ (Rehearsal) with 3.85; the lowest value of the entire sample. The highest value of this section is $\mathrm{O}$ (Organization) with 5.00.

The Resource Management section shows PE (Peer Learning) as the strategy with the lowest value of 4.01. The second lowest result in the entire sample. TE (Time and Study environment) also stands out for its high value (4.92) compared to the other strategies in this section.

Highlights of Lithuanian results: There is greater use of Motivation strategies with an overall average value of 4.82 . The second section of strategies with higher values is the Resource Management one with a global average value of 4.63. Finally, the section 
with lower perceived use of strategies is the Cognitive and Metacognitive section with an average of 4.31 .

That means that we can summarize the relationship between sections as follows:

$$
\text { CogMet }(4.31)<\operatorname{Adm}(4.63)<\operatorname{Mot}(4.82) \text {. }
$$

Considering the Motivation section, we can see a high dispersion within its values. In this section, we find the strategy with the highest value of the entire sample: LB (Control of Learning Beliefs) with 5.41. The strategy with the lowest value of this section is TA (Test Anxiety) with 3.86 of the mean value.

Regarding the Cognitive and Metacognitive section, we can see more uniform values with the exception of $\mathrm{O}$ (Organization) which shows the lowest value in the entire sample, 3.86. In this section, the strategy with the highest mean value is $\mathrm{R}$ (Rehearsal) with 4.68.

The Resource Management strategies section obtains the lowest value for PE (Peer Learning) with 4.38 and the highest value for SO (Support of others) with 4.89 on average.

\section{Comparison of results got in Lithuanian and Spanish cases}

Comparing both samples, the first difference to note is the fact that the average results obtained for Spanish students are generally higher than those obtained for Lithuanians. There is also a similitude based on the section with higher average values: motivational strategies section in both samples. Otherwise, the section progression found in the Spanish sample (Adm $<$ CogMet $<$ Mot) is not followed by the Lithuanian results (CogMet $<$ Adm $<$ Mot). That different progression is caused specially because of the high distance between the average value encountered in the Cognitive and Metacognitive scale for both samples, being 4.64 for Spanish students and 4.31 for the Lithuanian. Instead of this big distance, the Resource and Administration section does not show a significant difference: 4.56 vs 4.63 respectively.

A mixed ANOVA $3 \times 2$ was conducted for the MSLQ scores considering the nationality as the between subjects factor (Lithuanian/Spanish) and the scale as the with-in subject factor (15 scales). There was found the main sign effect of the intra-subject factor Scale Type (Block), with medium-high size, and a significant main effect of Nationality with a very small size and a significant interaction effect Scale Type (Block) Nationality although with small size.

The main effect of the nationality was significant but the effect size was small $(\mathrm{F}(1,428)=9,292 ; \mathrm{p}=.002 ; \mathrm{h} 2=.02 ; \mathrm{P}=.86)$.

This means that the global average of all the scales (the 15 included in the MSLQ questionnaire) is higher in the sample of Spanish students than in the Lithuanians, but the difference, although significant, is small in relative terms: $4.31(\mathrm{SD}=0.47)$ for Lithuanian and $4.79(\mathrm{SD}=0.40)$ for Spanish.

The main effect of the repeated measures factor, the scale, was also significant with a large effect size $(\mathrm{F}(14,415)=20,629 ; \mathrm{p}<.001 ; \mathrm{h} 2=, 41 ; \mathrm{P}=1$ ) (multivariate analysis, due 
to the violation of the sphericity condition: Mauchy test $\mathrm{W}=0.027 ; \mathrm{p}<.001$ ). Therefore there were clear differences among the scores for the different scales when the two samples were collapsed.

In addition, it is also appreciated that the effect of interaction origin $\mathrm{X}$ scale is significant and with large effect size: $\mathrm{F}(14,415)=25,891 ; \mathrm{p}<.001$; $\mathrm{h} 2=, 47 ; \mathrm{P}=1$ (multivariate, because sphericity cannot be accepted according to the Mauchy test: $\mathrm{W}=0.027 ; \mathrm{p}<.001)$. This means that the distribution of averages in the scales is different for the two samples.

The results showed the scales TA, R, E, O, MR are significantly different between both samples These differences show significantly higher averages in the Spanish sample for the TA, E, O, MR scales and higher averages for the Lithuanian sample in Rehearsal strategy. The highest difference is in the scale of Organization $(\mathrm{O})$ with much higher values for the Spanish sample $(5.01>3.54)$.

\section{Students understanding: results of qualitative approach}

The research was expanded with a qualitative to introduce a deeper understanding of the nature of the responses obtained. Analysis of the transcribed interviews increased the reliability of the statistical results obtained after completing the MSLQ questionnaire attending to:

(i) students' understanding about the questions included in the MSLQ questionnaire;

(ii) students' own description of the different strategies included on the MSLQ questionnaire.

After the standard process of interviews analysis the following featured results were drawn:

\section{Lithuanian case}

i. Students expose a relationship between study and memorization.

ii. The preference for autonomous study through preparing the own class notes or the practice of exercises.

iii. Team learning is appreciated as positive thanks to what the visions of classmates provide.

iv. A relationship between interest and motivation is shown when the topics are related to the student's daily life.

$v$. Interest is linked to the type of content and the prior existence of self-interest.

vi. The interdisciplinary connection between the scientific content is considered important.

vii. The difficulty is related to the previous interest. They also establish a relationship between motivation and prior interest. 


\section{Spanish case}

i. Students show a direct relationship between the concepts "studying" and "memorizing" or "writing".

ii. Students show a preference for activities that allow them to work autonomously.

iii. Good achievements in study connected to memorization are linked to the humanities disciplines, on the other hand, understanding concepts is connected to science disciplines.

iv. The study of science is associated with a higher level of effort and with a lot of content.

v. A general preference towards the more experiential activities is shown: storytelling, laboratory, examples, everyday life relationship.

vi. A priori interest and motivation are associated with the effort necessary to learn science.

vii. The methodology used by the teacher is linked to student motivation despite the fact that motivation is understood to be a shared responsibility between teacher and student.

viii. Curiosity is related to interest in science. Furthermore, interest is related to less effort required due to existing motivation. Boredom is associated with the amount of content and the type of explanation.

\section{Discussion}

The combination of questionnaire and interview analysis has shown a clear preference for a more autonomous study based on decisions that the student can carry out by him/ herself individually or in groups to understand in depth what is required for the study of science. The important differences were observed in the "Organization $(\mathrm{O})$ " strategy with much higher values for the Spanish sample (5.01 > 3.54) [from table 2]. As Pintrich et al. (1991) mention in the MSLQ questionnaire definition, the organization strategies help the student to select the appropriate information and build connections between the information to be learned, this implies greater participation in the task. Therefore, the difference found in this strategy shows that Spanish schools further encourage student autonomy due to their need to be involved in the study. To abound in this difference, the values found for the T.A Test Anxiety strategy $(4.7>3.9)$ [from table 2] among the samples suggest a greater use of examination-type evaluation tests in the Lithuanian secondary school and therefore the anxiety towards them due to the use of memorization for their study.

The differences found between the two samples may open up some findings; on the one hand, it seems that Lithuanian students answered in a more 'cautious' way their selfassessment compared to the Spanish ones. This caution shown by the Lithuanian students could be associated with the sociocultural reality existing between both contexts: while the Spanish secondary schools are all urban and close to the city, the Lithuanian center is 
situated in a rural environment. This different situation in terms of location, in addition to that of the country where they are located, entails an important difference between both realities where the treatment between teacher and students is different. Evidence of this statement is manifested in the way of addressing teachers; while in all the Spanish schools in the sample the students address the teacher by name, in the Lithuanian school the way of addressing teachers as "Teacher + Surname" still persists, for example, teacher Ortega. Therefore, this precautionary effect on the responses of Lithuanian students may be conditioned by what they suppose teachers prefer.

On the similarities between the two samples related to the students' assumption of responsibility the results shown that, independently from their sociocultural environment they prefer to assume their own responsibility in the study through autonomous work. They also grant a large part of this possibility to the teacher's action through the link between generating interest in the subject according to the chosen methodology. In the same way, they show interest in the interdisciplinary connection of the contents worked on. One of the consequences that could arise from this assumption of responsibility is the need to investigate the effects of different instructional methods focused on self-regulation strategies. To date, Inquiry-Based learning (Şen, et al., 2015) and Problem-Based learning (Sungur \& Tekkaya, 2006) have shown greater autonomy to students learning process than traditional instructional approaches in various facets of self-regulated learning of the students.

According to the model by Nelson et al. (1990), two sub-processes can be distinguished in metacognitive monitoring: vigilance and control. These two processes are responsible of the subject's detection of a comprehension obstacle and the actions students made (trying) to overcome the obstacle. Actions related to the strategies they use. Significant effects of monitoring skills have been obtained also in Science education at secondary school (Sanjosé et al., 2010). As Regulatory strategies concerns, long time ago Wang et al. (1993) obtained evidence about the influence of students' comprehension monitoring on academic success, greater than the rest of educational, familiar and curricular to maintain their students working on.

\section{Conclusions, Implications and Limitations}

Based on the current results, we can conclude that the use of learning strategies on secondary education science learning is important in any sociocultural environment. The students evaluate this importance and their influence on the learning process regardless of their environment.

There are some strategies with more influence, especially those connected with motivation so teachers have to consider them when planning their lessons. The influence of the teacher is also an important coincidence on the student's perception. 
In addition, there is an important improvement opportunity instructing students to use metacognitive learning strategies with more responsibly, this is a promising way to improve science performance in any sociocultural environment.

Science teachers and teachers in any discipline should include an instruction to help students manage their own learning strategies in their daily lessons; even more in secondary education.

There is a limitation in the comparison of data from the present study because the samples are not balanced in Spain and Lithuania. It could be interesting to amplify the sample in Lithuania to analyze the representation of the sample taken in this article and also to find deeper similarities or differences between courses or ages.

\section{References}

Arslan, A. (2013). Investigation of relationship between sources of self-efficacy beliefs of secondary school students and some variables. Educational sciences: theory and practice, 13(4), 1983-1993. Akyol, G., Sungur, S., \& Tekkaya, C. (2010). The contribution of cognitive and metacognitive strategy use to students' science achievement. Educational Research and Evaluation, 16(1), 1-21.

Bembenutty, H. (2009). Feeling-of-knowing judgement and self-regulation of learning. Education, 129(4), 589-598.

Bircan, H. and Sungur, S. (2016). The role of motivation and cognitive engagement in science achievement. Science Education International, 27(4), 509-529.

Bryan, R. R., Glynn, S. M., \& Kittleson, J. M. (2011). Motivation, achievement, and advanced placement intent of high school students learning science. Science Education, 95(6), 1049-1065. http://dx.doi.org/10.1002/sce.20462

Brown, A. L., \& Palincsar, A. S. (1982). Inducing strategic learning from texts by means of informed, self-control training. Center for the Study of Reading Technical Report, no. 262.

Curione, K. (2017). MSLQ-UY, validación con estudiantes universitarios uruguayos [MSLQ-UY validation with Uruguayan university students]. Revista Evaluar, 17(2), 17-18.

Dewey, J. (2007). Experience and education. New York, NY: Simon and Schuster.

Greene, B. A., \& Miller, R. B. (1996). Influences on achievement: Goals, perceived ability, and cognitive engagement. Contemporary Educational Psychology, 21(2), 181-192. http://dx.doi. org/10.1006/ceps.1996.0015

Ilker, E. (2014). A validity and reliability study of the motivated strategies for learning questionnaire. Educational Sciences: Theory and Practice, 14(3), 829-833.

Koballa, T. R., \& Glynn, S. M. (2013). Attitudinal and motivational constructs in science learning. In S. K. Abell, K. Appleton, and D. L. Hanuscin (Eds.), Handbook of research on science education (pp. 89-116). Routledge. 
Lee, J. C. K., Zhang, Z., \& Yin, H. (2010). Using multidimensional Rasch analysis to validate the Chinese version of the Motivated Strategies for Learning Questionnaire (MSLQ-CV). European Journal of Psychology of Education, 25(1), 141-155.

Lewalter, D. (2003). Cognitive strategies for learning from static and dynamic visuals. Learning and Instruction, 13(2), 177-189. http://dx.doi.org/10.1016/S0959-4752(02)00019-1

Lynch, D. J. (2008). Confronting challenges: Motivational beliefs and learning strategies in difficult college courses. College Student Journal, 42(2), 416-422.

Mega, C., Ronconi, L., \& De Beni, R. (2014). What makes a good student? How emotions, selfregulated learning, and motivation contribute to academic achievement. Journal of Educational Psychology, 106(1), 121. http://dx.doi.org/10.1037/a0033546

Nelson, T. O., \& Narens, L. (1990) Metamemory A theoretical framework and some new findings. In G. H. Bower (Ed.), The psychology oflearning and motivation, 26, (pp. 125-173). San Dego: Academic Press.

Ortega-Torres, E., Sanjose, V., \& Solaz, J. J. (August, 2018) Sensorial preferences of learning of the sciences of the pupils of secondary [Conference presentation], Proceedings of Constructionism, Computational Thinking and Educational Innovation: conference. Vilnus, Lithuania.

Ortega-Torres, E. (2019). Sensory preferences and self-perceived use of strategies in the learning of science of secondary students: analysis and instructional proposal [Doctoral dissertation, Valencia university].

Pintrich, P. R., Smith, D. A. F., Garcia, T., \& McKeachie, W. J. (1991). A manual for the use of the Motivated Strategies for Learning Questionnaire (MSLQ) (Tech. Report No. 91-B-004). Boards of Regents, University of Michigan, Ann Arbor, MI.

Sanjosé, V., Fernández, J. J., \& Vidal-Abarca, E. (2010). Importancia de las destrezas de procesamiento de la información en la comprensión de textos científicos [Importance of information processing skills in understanding scientific texts]. Infancia y Aprendizaje, 33(4), 529-541.

Şen, Ş., Y1lmaz, A., \& Geban, Ö. (2015). The effects of process oriented guided inquiry learning environment on students' self-regulated learning skills. Problems of Education in the 21st Century, 66, 54-66.

Sungur, S., \& Güngören, S. (2009). The role of classroom environment perceptions in self-regulated learning and science achievement. Elementary Education Online, 8(3), 883-900.

Sungur, S., \& Tekkaya, C. (2006). Effects of problem-based learning and traditional instruction on self-regulated learning. The Journal of Educational Research, 99(5), 307-320. http://dx.doi. org/10.3200/JOER.99.5.307-320

Veloo, A., Hong, L. H., \& Lee, S. C. (2015). Gender and ethnicity differences manifested in chemistry achievement and self-regulated learning. International Education Studies, 8(8), 1. Wang, M. C., Haertel, G. D., \& Walberg, H. J. (1993). Toward a knowledge base for school learning. Review of Educational Research, 63(3), 249-294. https://doi.org/10.2307/1170546 


\title{
Mokymosi strategijų panaudojimas Ispanijos ir Lietuvos vidurinių mokyklų mokiniams mokantis gamtamokslinių ir matematikos mokomujų dalykų: savęs suvokimo lyginamoji analizè
}

\author{
Enric Ortega-Torres ${ }^{1}$, Sigitas Drąutis ${ }^{2}$, Renata Burbaite ${ }^{3}$
}

\begin{abstract}
Floridos universitetas, Valensijos universitetas, ES-46470 Kararocha, Valensija, Ispanija, eortega@florida-uni.es Kauno technologijos universitetas, Informatikos fakulteto programinès ịrangos inžinerijos katedra, Studentu g. 50-416, 51368 Kaunas, sigitas.drasutis@ktu.lt

3 Kauno technologijos universitetas, Informatikos fakulteto programinės ịrangos inžinerijos katedra, Studentų g. 50-416, 51368 Kaunas, frenata.burbaite@ktu.lt
\end{abstract}

\section{Santrauka}

Norint užtikrinti sẻkmingą mokymąsi, svarbu vystyti ir tobulinti besimokančiųjų mokymosi strategijas. Mokymosi strategijų pažinimas taip pat svarbus siekiant suprasti besimokančiųjų mokymosi procesus. Šiame straipsnyje pristatomo tyrimo tikslai buvo šie: a) palyginti Ispanijos ir Lietuvos moksleivių, besimokančių bendrojo ugdymo mokyklose, mokymosi strategijų suvokimą mokantis gamtamokslinių ir matematikos mokomųjų dalykų (angl. science subjects); b) išanalizuoti moksleivių suvokimą apie taikytas mokymosi strategijas ir c) nustatyti socialinès ir kultūrinès aplinkos poveikį, susijusị su mokymosi strategijų suvokimu, moksleiviams. Motyvuotu mokymosi strategijų klausimynas (angl. MSLQ) buvo naudojamas kaip validuota priemonė ịvertinti moksleivių suvokimą apie mokymosi strategijų naudojimą, šia priemone buvo siekiama ịvertinti moksleivių mokymosi strategijų suvokimo lygị ir akademinę motyvaciją. Motyvuotų mokymosi strategijų klausimynas (angl. The Motivated Strategies for Learning Questionnaire (MSLQ)) pateiktas 365 Ispanijos ir 65 Lietuvos bendrojo ugdymo mokyklų moksleiviams. Interviu su moksleiviais metu buvo siekiama pagilinti jų suvokimą apie mokymosi strategijas mokantis gamtamokslinių ir matematikos mokomųjų dalykų. MSLQ balai kiekvienam skirsniui ir komponentui buvo lyginami abiejose apklausose, siekiant nustatyti ar: 1) mokymosi strategijų itaka yra svarbi mokantis gamtamokslinių ir matematikos mokomųjų dalykų bet kurioje socialinejje ir kultūrineje aplinkoje; ar 2) motyvaciniai komponentai turi didesnị poveikị moksleivių suvokimui apie mokymosi strategijų itaką. Gauti rezultatai parodo paramos veiksmų ịtraukimo svarbą i mokslo mokymosi planus, kuriais siekiama pagerinti vidurinès mokyklos moksleivių strategijų valdymą, rengimą.

Esminiai žodžiai: mokymosi strategijos, motyvacija, gamtamoksliniu ir matematikos mokomujų dalykų mokymasis, bendrasis ugdymas, motyvuotu mokymosi strategijų klausimynas. 